\title{
The effect of corporate social responsibility on
}

\section{Malaysian financial institutions' dividend payout [version 1;}

\section{peer review: 2 approved with reservations]}

\author{
Abdullah Sallehhuddin (D1), Teo Boon Keong (iD)2, Norzarina Md Yatim(iD) \\ ${ }^{1}$ Faculty of Management, Multimedia University, Cyberjaya, Selangor, 63100, Malaysia \\ ${ }^{2}$ Syarikat Takaful Malaysia Keluarga Berhad, Menara Takaful Malaysia, No.4, Jalan Sultan Sulaiman, Kuala Lumpur, 50450, Malaysia
}

V1 First published: 14 Jan 2022, 11:47

https://doi.org/10.12688/f1000research.73603.1

Latest published: 14 Jan 2022, 11:47

https://doi.org/10.12688/f1000research.73603.1

\section{Abstract}

Background: The corporate social responsibility (CSR) disclosure was made mandatory in Malaysia in 2007 with the introduction of the CSR Framework by Bursa Malaysia. Since then, the practice of CSR disclosure is growing, as Malaysia joins global efforts towards sustainable development. Despite increased research on CSR; limited studies are assessing the relationship of specific

dimensions - environmental, community, workplace and marketplace, towards dividend payout, which is crucial to investment and corporate financial decision making.

Method: The study involved 32 Malaysian public listed finance companies as of 2017. It deployed data from annual reports and databases. Additionally, the study used content analysis to measure the CSR disclosure score, and dividend payout was calculated from the database.

Results: There was a significant correlation between community and workplace dimensions with dividend payout. Despite the absence of significant results, the regression analysis showed a positive relationship between community and workplace dimensions with dividend payout. Besides, there was an inverse relationship between the environmental and marketplace dimension with dividend payout. The results indicated that active involvement in the community dimension resulted from an immediate positive impact towards brand equity, attracting current and new customers, and therefore improving the earning levels and dividend payout. Additionally, greater participation in the workplace dimension solidifies employees' engagement and motivation, improves the productivity level, which can be translated into enhanced earning levels and dividend payout. Meanwhile, participation in environmental and marketplace dimensions requires a longer period to yield an
Open Peer Review

\begin{tabular}{lcc} 
Approval Status & $?$ \\
& 1 & 2 \\
\hline version 1 & $?$ & $?$ \\
14 Jan 2022 & view & view
\end{tabular}

1. Shaista Wasiuzzaman (D), Universiti Teknologi Brunei, Bandar Seri Begawan, Brunei

\section{Bakhtiar Alrazi (iD), Universiti Tenaga}

Nasional, Muadzam Shah, Malaysia

Any reports and responses or comments on the article can be found at the end of the article. 
impact, higher development expenditure, and involve sensitive information that might benefit competitors. Hence, companies tend to utilise internal funding instead of redistributing the wealth through dividend payout.

Conclusion: The study contributes to the literature of CSR by explaining the relationship of specific dimensions of environmental, community, workplace, and marketplace towards dividend payout using the evidence from the emerging economy.

Keywords

Environmental, Community, Workplace, Marketplace, Corporate Social Responsibility, Dividend Payout, Finance Companies, Malaysia.

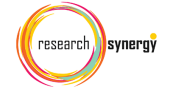

This article is included in the Research Synergy

Foundation gateway.

Corresponding author: Abdullah Sallehhuddin (abdullahsallehhuddin@gmail.com)

Author roles: Sallehhuddin A: Conceptualization, Investigation, Methodology, Supervision, Writing - Original Draft Preparation, Writing - Review \& Editing; Boon Keong T: Conceptualization, Formal Analysis, Investigation, Methodology, Writing - Original Draft Preparation; Md Yatim N: Conceptualization, Methodology, Writing - Original Draft Preparation, Writing - Review \& Editing

Competing interests: No competing interests were disclosed.

Grant information: The author(s) declared that no grants were involved in supporting this work.

Copyright: $\odot 2022$ Sallehhuddin A et al. This is an open access article distributed under the terms of the Creative Commons Attribution License, which permits unrestricted use, distribution, and reproduction in any medium, provided the original work is properly cited.

How to cite this article: Sallehhuddin A, Boon Keong T and Md Yatim N. The effect of corporate social responsibility on Malaysian financial institutions' dividend payout [version 1; peer review: 2 approved with reservations] F1000Research 2022,11 :47 https://doi.org/10.12688/f1000research.73603.1

First published: 14 Jan 2022, 11:47 https://doi.org/10.12688/f1000research.73603.1 


\section{Introduction}

Corporate Social Responsibility (CSR) has been around for decades, which was initially carried out voluntarily. Later, encouraged and enforced by governments and authorities, CSR is deployed to create a better sustainable business environment (Bursa Malaysia, 2012). However, there are mixed arguments in CSR, where some companies view it as capital reduction while others view it as value creation (Nekhili, Nagati, Chtioui \& Rebolledo, 2017; Robinson, Kleffner \& Bertels, 2011; Margolis \& Walsh, 2003). Although the worldwide business environment started to boost CSR disclosure (PwC, 2017; KPMG, 2015), there is still room for further development of CSR practices, particularly for an emerging and developing market like Malaysia. At the start of 2017, CSR practice and disclosure in Malaysia started to surge since it was made mandatory by the government for publicly listed companies to disclose CSR initiatives in their annual reports (Bursa Malaysia, 2012). The CSR disclosure framework issued by Bursa Malaysia in 2006 governs the CSR disclosure in Malaysia. The framework consists of four dimensions of CSR, namely (1) environmental, (2) workplace, (3) community, and (4) marketplace (Bursa Malaysia, 2012). This framework governed public companies' CSR disclosure and was incorporated as a new rule in Bursa Malaysia Listing Requirement. Before 2006, CSR disclosure by Malaysian public listed companies was voluntary, and public listed companies' level of disclosure was not encouraged (Lim, Talha, Junaini \& Sallehhuddin, 2008). Moreover, despite the enforced CSR disclosure, the framework does not contain details of measurement criteria of CSR disclosure; therefore, multiple formulas to measure the CSR disclosure level was proposed by a prior study (Mohanadas, Sallehhuddin \& Lim, 2019; Lim et al., 2008; Williams \& Ho, 1999; Hackston \& Milne, 1996).

To date, numerous studies have analysed the CSR in Malaysia such as Sulaiman, Abdullah and Fatima (2014), Saleh, Zulkifli and Muhamad (2010), and Nik Ahmad, Sulaiman and Siswantoro (2003). Studies by Yam (2013) and Nik Ahmad and Haraf (2011) focused on CSR disclosure for a specific economic sector, i.e., property development. In general, studies found a significant increase in the extent and quality of CSR disclosure in Malaysia (Haji, 2013). There were also studies on the impact of CSR on organisational performance, such as financial performance by Selvarajah, Murthy and Massilamani (2018), tax aggressiveness by Mohanadas et al. (2019), and the antecedents of CSR disclosure by Lim et al. (2008). However, there are limited studies on the impact of CSR reporting on dividend payout even though it is one of the most crucial parts of corporate finance as investors use it to analyse the future cash flow of the business (Fama \& French, 2001).

Additionally, dividend payout influences ethical investors decision in placing their money in socially, environmentally, and ethically compliant companies (Hellsten \& Mallin, 2006). Besides, Cheung, Hu and Schwiebert (2018) and Benlemlih (2019) suggested that higher CSR performing companies in the United States, tend to pay higher dividends than lower-performing peers. Therefore, as Malaysia moves towards achieving the United Nation's Sustainable Development Goals (SDG), it is essential to determine the interactions of CSR reporting and dividend payout. Besides, investors may factor in CSR performance in determining dividend payout to make a better justifiable investment decision.

Moreover, it helps to discover the extent of CSR influence on the distribution of wealth among companies. Hence, this study will examine the relationship of each dimension of CSR stipulated by the CSR Framework 2006 of Bursa Malaysia and dividend payout of public listed financial companies. This study attempts to answer the relationship between environmental dimension, community dimension, workplace dimension and marketplace dimension towards dividend payout. In short, the study intends to pioneer the investigation of specific CSR dimension performance on dividend payout in the Malaysian context, in particular among financial institutions.

The outcomes of this study contributed to the body of literature in several ways. First, this study provided new evidence on the relationship between CSR performance and dividend payout among companies, particularly finance companies in the emerging market. Previously, Hendijani Zadeh (2020), Sheikh (2020), Benlemlih (2019), Cheung et al. (2018), Samet and Jarboui (2017), and Rakotomavo (2012) examined this relationship; however, this study focused on the developed market which has a different economic policy, developmental rate, cultural and priorities. Moreover, Cheung et al. (2018) and Rakotomavo (2012) concentrated the analysis on overall CSR disclosure instead of specific CSR dimension. Besides, Hendijani Zadeh (2020), Sheikh (2020), and Samet and Jarboui (2017) excluded the financial sector in the final analysis. Second, despite the effort by Saeed and Zamir (2021) and Trihermanto and Nainggolan (2019) to assess the impact of CSR involvement on dividend payment in an emerging market, the findings remain inconsistent and inconclusive. Additionally, Nguyen and Nguyen (2021) attempted to evaluate the impact of CSR involvement among commercial banks in Vietnam; however, the study concentrated on measuring the risk-taking behaviour rather than a dividend payment. Therefore, this study offered new findings on the impact of specific CSR dimensions on dividend payout, particularly among financial institutions in the emerging market. Third, this study added to the literature of dividend payout antecedent by explaining the impact of non-financial factors, like CSR disclosure. The encouragement to examine non-financial factors towards dividend policy is emphasised by Pinto, Rastogi, Kadam and Sharma (2020) 
and Al-Najjar and Kilincarslan (2019). Besides, existing studies in emerging and developing markets like Budagaga (2020) and Dewasiri, Koralalage, Azeez, Jayarathne, Kuruppuarachichi and Weerasinghe (2019) heavily concentrated on financial factors towards dividend policy.

\section{Literature review}

Broadly, there are two possible explanations for the relationship between CSR and dividend payout. First, companies enhance their involvement and participation in CSR to strengthen their brand reputation and secure public accolades (Cespa \& Cestone, 2007). Second, CSR is one of the strategies to formulate a positive attitude among the public towards a particular company (Harjoto \& Jo, 2014). The boost of the positive corporate image is expected to improve sales and protect companies from market uncertainties (El Ghoul, Guedhami, Kwok \& Mishra, 2011), including competitors (Bae, El Ghoul, Guedhami, Kwok \& Zheng, 2019). As a result, better sales and market share control shall contribute to the enhancement of revenue. Subsequently, as the earnings level improves, a company can announce a higher dividend payout to shareholders. Besides, CSR becomes a marketing and publicity tool for a company to maintain loyalty among existing customers as it creates a feeling of association with a positive brand. Then, the existing groups of current customers are expected to improve purchasing level, leading to better earnings and, eventually, a higher dividend payout. Additionally, CSR becomes a marketing tool to attract new customers by utilising strong brand associates with good deeds or philanthropic initiatives to a deprived community. Heal (2005), in summary, contended that an improved CSR involvement leads to better earnings through brand equity, a better connection with stakeholders, boost employee productivity, and improved asset allocation.

Secondly, CSR relates to dividend payout by lowering the cost of capital. The greater involvement of companies in CSR activities usually leads to a better disclosure level of information on companies' profiles. As more details become public, it increases transparency and reduces information asymmetry (Chauhan \& Kumar, 2018). This translates to a lower cost of gathering or collecting information about a particular company among investors, creditors, or financiers. Subsequently, it reduces the cost of issuing and raising capital among companies that actively participate in CSR programmes. Effective cost management leads to improvement of earnings level, which later translated to a higher dividend payout. From a different perspective, as argued by Benlemlih (2019) and Goss \& Roberts (2011), less socially responsible companies (e.g., alcohol, tobacco and military \& weaponry) commonly confront a higher cost of capital or exorbitant external financing. Consequently, these companies prefer to keep their cash for future internal funding than redistribute the wealth through a higher dividend payout.

A study by Benlemlih (2019) observed 3040 companies in the United States from 1991 to 2012. The findings indicated that a strong performing of CSR companies tends to declare a higher dividend payout, while less performing CSR companies typically report a lower dividend payout. A further assessment evidenced that a strong performing of CSR companies' community, environmental, and workplace dimensions positively correlated with dividend payout. Only marketplace dimension had an inverse relationship with dividend payout. Benlemlih (2019) and Bah \& Dumontier (2001) argued that the marketplace dimension instituted product development which involved strategic and sensitive information. Companies prefer to cover product innovation or product development expenditure through internal financing to avoid exposure to competitors. Hence, companies keep the cash within the organisation instead of redistributing the wealth through dividend payout. Earlier, Cheung et al. (2018) examined 1965 companies in the United States covering 1991 to 2010. The panel data set analysis also evidenced that a company with strong participation in CSR is positively related to a higher dividend payout.

Meanwhile, a study by Kim and Jeon (2015) examined the relationship between CSR and dividend payout in Korea. The study found that the parent companies direct the dividend policy of multinational companies' subsidiaries in Korea. The findings also found a weak correlation between CSR and dividend payout among foreign subsidiaries compared to the local Korean companies. Additionally, Samet and Jarboui (2017) evaluated CSR involvement with dividend policy among European firms. The study observed 397 data of a firm from 2009 to 2014, which indicated that a socially responsible firm pays a higher dividend than a less socially responsible counterpart. Besides, using 17670 of the United States firm-year observations from 1991 to 2007, Rakotomavo (2012) established that a more mature company is willing to increase spending on CSR without lowering the expected dividend payout. Thus, there was a direct relationship between CSR spending and dividend payout. However, like Samet \& Jarboui (2017), Rakotomavo (2012) also omits the individual CSR dimension analysis on dividend payout. In a more recent investigation, Hendijani Zadeh (2020) deployed 2,822 of the United States' firm-year observations of Standard and Poor's (S\&P) 500 index firms from 2012 to 2019. The study examined the impact of environmental CSR and social CSR disclosures on companies' dividend payout. The findings indicated that the higher disclosure of both dimensions leads to a higher dividend payout. Additionally, the findings revealed that the dividend payout was more stable among firms with high environment CSR and social CSR disclosures than fewer disclosure firms. Meanwhile, Sheikh (2020) used the United States' 24,215 firm-year 
observations of the Morgan Stanley Capital International (MSCI) (previously KLD) database for 2003 to 2018. The findings discovered a positive relationship between CSR performance and dividend payment. Furthermore, the relationship was significant when companies operated in a less competitive market. However, there was a nonsignificant relationship between CSR performance and dividend payment among firms operating in a competitive market.

In an emerging market context, Saeed and Zamir (2021) checked the relationship of CSR involvement with dividend payout in India, China, Indonesia, Pakistan, Malaysia, Korea, Turkey, and Russia. The investigation selected the top 250 companies in terms of market capitalisation from each country. After several filtering considerations, the final sample covered 721 companies but omitting finance companies (India - 180, China - 162, Indonesia - 42, Pakistan - 50, Malaysia - 80, Korea - 109, Turkey - 51 and Russia -47), covering the period of 2010-2018. The study also revealed a similar pattern, where there was an inverse relationship between CSR involvement and dividend payout in the understudy emerging markets. In terms of individual CSR effect, the study also found that community and environmental dimensions had an inverse relationship with dividend payout, with the community dimension experiencing greater magnitude than the environmental dimension. Besides, Trihermanto and Nainggolan (2019) observed 527 Indonesian firms' data $(2008$ - 2015) to assess the impact of CSR involvement towards dividend payment. The study found that there was a positive relationship between CSR expenses and firms' dividend payments. Similar positive relationships were also established for CSR social dimension and CSR environmental dimension. However, there was a negative relationship between CSR economic dimension and firms' dividend payment. The study measured CSR economic dimensions by considering the expenses spent for business partnership projects, community development and infrastructure projects. In addition, Nguyen and Nguyen (2021) evaluated 30 Vietnamese commercial banks' data for 2008 to 2017. Even though dividend payment was not directly measured, the variable was considered a form of risk, and the inability to meet the commitment was perceived to increase the banks' risks. Besides, the study did not count for specific CSR dimensions. However, the study found that financially constrained commercial banks reduced CSR expenses to manage risk like meeting dividend commitment, while financial unconstrained commercial banks were more likely to increase CSR expenses and exhibited a high risk-taking attitude.

Based on the mentioned arguments, there are four hypotheses formulated in the current study to examine the relationship between each dimension of CSR disclosure and dividend payout. The hypotheses are as follow:

$\boldsymbol{H}_{1}$. There is a positive relationship between the environmental dimension of CSR and dividend payout.

$\boldsymbol{H}_{2}$. There is a positive relationship between the community dimension of CSR and dividend payout.

$\boldsymbol{H}_{3}$. There is a positive relationship between the marketplace dimension of CSR and dividend payout.

$\boldsymbol{H}_{4}$. There is a positive relationship between the workplace dimension of CSR and dividend payout.

\section{Methods}

The four dimensions of CSR disclosure served as independent variables, and the dividend payout served as a dependent variable. Environmental dimension (CSR_E) focused on finance company's disclosure relating to environmental efforts. Community dimension (CSR_C) referred to the finance company's disclosure on contributing back to the community where the business is operating. The marketplace dimension (CSR_M) focused on the finance company's disclosure of products and services offered to the market and the concerned customers' satisfaction. The workplace dimension (CSR_W) refers to financing a company's effort to provide a suitable working environment that promotes equality, fairness, and safety. Finally, dividend payout (DivPay) concentrated on the percentage of dividend payment over the financial companies' earnings.

As of 2017, there were 32 public listed finance companies at Bursa Malaysia. According to Krejcie and Morgan (1970), a sample size of 28 is appropriate for a population size of 32 . Nevertheless, the study captured and analysed the entire 32 finance companies. These finance companies were differentiated into five categories: credit service provider, insurance, banks, and exchange and investment holdings. In specific, the sample included 10 retail banks, one exchange, ten investment holding companies, eight insurance companies and three credit service providers (See Extended data A) (Sallehhuddin, Keong \& Yatim, 2021a). 2017 Data was chosen for this study as it represented the complete fiscal year of finance companies' performance during the last year of the implementation of the National Transformation Policy by the sixth Prime Minister Najib Razak. The policy was ceased after the defeat of the ruling party since the independence in 1957-Barisan National (Alliance Front) in the 14th General Election in May 2018 (Nadzri, 2018)

Annual reports of finance companies in 2017 were referred to obtain data from each CSR dimension. In addition, the study also referred to Bursa Malaysia and Bloomberg databases for information on finance companies' dividend payout. Content analysis was used to analyse CSR disclosure performance from annual reports and databases. Content analysis 
has been widely deployed to measure CSR disclosure and it is considered to be the most reliable method (Parsa, Roper, Muller-Camen \& Szigetvari, 2018; Zamir \& Saeed, 2020; Haniffa \& Hudaib, 2007). The variables were analysed by utilising the 120 measurement criteria adopted by Shirley, Suan, Leng, Okoth and Fei (2009), Williams and Ho (1999) and Hackston and Milne (1996). There were 47 environmental items, nine community items, 15 marketplace items, and 49 workplace items. The example of each CSR dimension's items is presented in Extended Data B (Sallehhuddin, Keong \& Yatim, 2021b). The score of "1" was assigned for disclosure of CSR items while " 0 " for non-disclosure of CSR items. Then, the total score of each CSR dimension was computed in terms of percentage. Moreover, dividend payout is computed in a ratio by determining the amount the company pays its shareholder in the form of dividends from its earnings.

Data analysis consisted of univariate analysis, where descriptive statistic such as mean, standard deviation, minimum and maximum was presented. Then, bivariate analysis was deployed to analyse the relationship between each dimension with dividend payout. Subsequently, the multivariate analysis assessed the simultaneous interactions among multiple variables under study. Finally, the results of the multivariate analysis were also referred to for hypothesis testing. Analysis was carried out using SPSS 24.

\section{Results}

Table 1 depicts the descriptive analysis. These results show that there were finance companies without involvement in environmental and community-related CSR programmes. On average, finance companies recorded a higher involvement in community-related programmes with $65 \%$, followed by involvement in marketplace-related projects. Conversely, the lowest involvement of finance companies was in environmental-related programmes. In addition, on average, the dividend payout for finance companies was 41.18 .

Table 2 shows the correlation analysis. There was a significantly positive correlation between the community dimension and workplace dimension with dividend payout. In addition, there was a positive and non-significant correlation between environmental dimension and marketplace dimension with dividend payout. Besides, there was a strong and significant correlation among the four dimensions of CSR. For instance, the workplace dimension was strongly and significantly related to environmental, community, and marketplace dimensions. It implied that finance companies could actively engage the workforce or garner employees support to execute CSR programmes. It also reflected that finance companies organised awareness workshops or provided training for employees to familiarise the workforce in CSR initiatives. The strong correlation could also be attributed to a series of CSR initiatives executed by employees that benefited from more than one dimension concurrently.

Table 1. Descriptive analysis $(n=32)$.

\begin{tabular}{|l|l|l|l|l|}
\hline & Min & Max & Mean & Std deviation \\
\hline CSR_E & 0.00 & 0.96 & 0.56 & 0.22 \\
\hline CSR_C & 0.00 & 0.89 & 0.65 & 0.26 \\
\hline CSR_M & 0.11 & 1.00 & 0.60 & 0.25 \\
\hline CSR_W & 0.11 & 0.94 & 0.57 & 0.22 \\
\hline Div Pay & 0.00 & 97.93 & 41.18 & 29.91 \\
\hline
\end{tabular}

Table 2. Correlation analysis $(n=32)$.

\begin{tabular}{|l|l|l|l|l|}
\hline & CSR_E & CSR_C & CSR_M & CSR_W \\
\hline CSR_E & 1 & & & \\
\hline CSR_C & $0.625^{\star *}(0.00)$ & 1 & & \\
\hline CSR_M & $0.719 * *(0.00)$ & $0.598^{* *}(0.00)$ & 1 & 1 \\
\hline CSR_W & $0.742^{* *}(0.00)$ & $0.820^{* *}(0.00)$ & $0.753^{* *}(0.00)$ & $0.384^{*}(0.03)$ \\
\hline Div Pay & $0.220(0.227)$ & $0.409^{*}(0.02)$ & $0.170(0.352)$ & 1 \\
\hline
\end{tabular}

**Correlation is significant at the 0.01 level $(2$ - tailed).

*Correlation is significant at the 0.05 level $(2-$ tailed). 


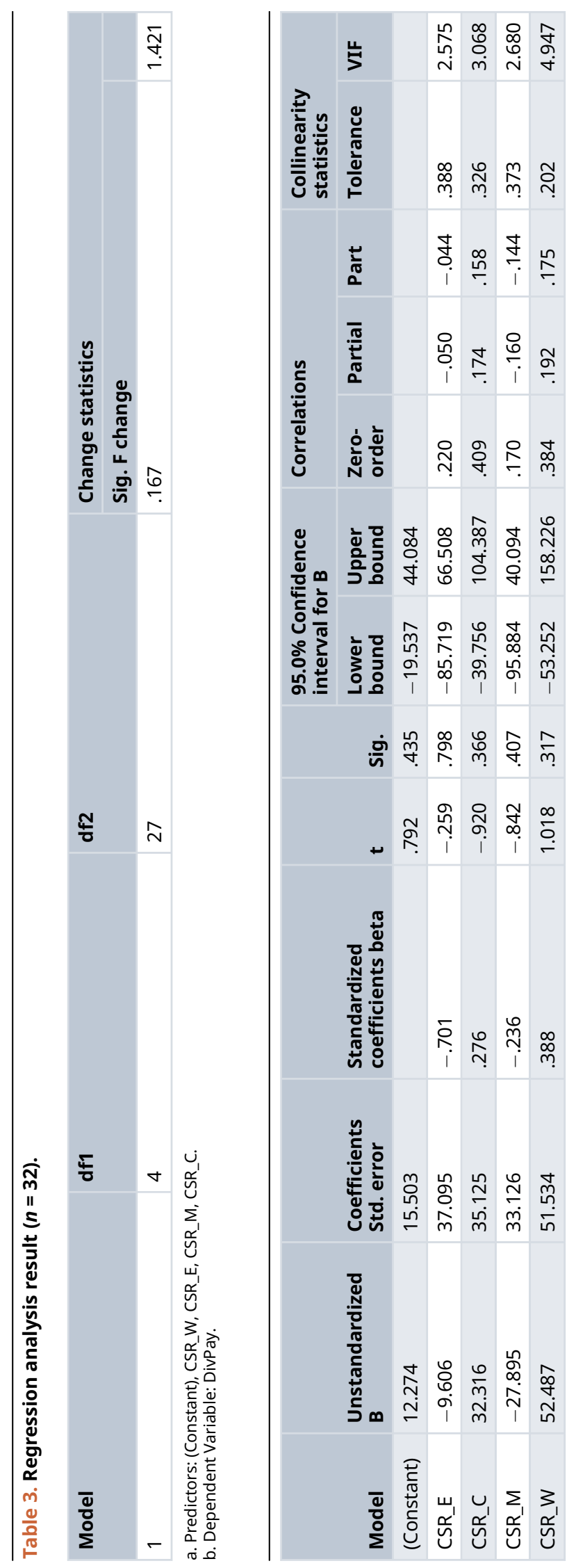


Table 3 indicates the multiple regression analysis results. The results yielded the R-square value of 0.206 , indicating $20.6 \%$ of the variation in dividend payout was explained by the four dimensions of CSR. Besides, the regression equation can be represented as follows:

$$
\begin{aligned}
\text { Dividend Payout }= & 12.274-9.606(\text { environmental })+32.316(\text { community })-27.895(\text { marketplace }) \\
& +52.487(\text { workplace }) .
\end{aligned}
$$

The equation can be interpreted as follows:

a. For every unit increase in environmental, dividend payout decreases by 9.606 units, provided other independent variables remain unchanged.

b. For every unit increase in a community, dividend payout increases by 32.316 units, provided other independent variables remain unchanged.

c. For every unit increase in the marketplace, dividend payout decreases by 27.895 units, provided other independent variables remain unchanged.

d. For every unit increase in the workplace, dividend payout increases by 52.487 units, provided other independent variables remain unchanged.

Workplace dimension had the highest impact on dividend payout, followed by community dimension. In terms of significant effect, the environment, the community, and the workplace had p-values of $0.798,0.336$, and 0.407 , respectively. Hence, all four dimensions of CSR had a $p$-value of more than 0.05 , indicating no significant impact on dividend payout. Despite non-significance indication for all four dimensions, the regression found positive relationships for community and workplace CSR dimension with dividend payout; hence, the study found support for hypotheses 2 and 4; however, the regression found negative relationships for environmental and marketplace CSR dimension with dividend payout; hence, the study did not find support for hypothesis 1 and 3.

\section{Discussion}

These findings were consistent with studies by Senawi, Abdul Rahman, Ahmad and Che Pin (2016) and Shirley et al. (2009), where like other sectors, finance companies also placed a higher weight on the community dimension, as compared to other dimensions of CSR. The community dimension is believed to be the easiest and quickest route to achieve immediate results of projecting the companies' positive brand, reputation, image, goodwill and developing a positive attitude in public (Harjoto \& Jo, 2014). The community dimension is about giving back to the public or community in the form of cash, non-cash or a kind gesture to society. The benefits are instantly reaped from activities of donating cash to a non-profit organisation and setting up scholarship schemes for underprivileged society. Companies can expect immediate recognition by contributing to community dimension activities, whereas investing in other dimensions like environmental, marketplace and workplace may not produce the immediate results or impact (Brown, Helland \& Smith, 2006). For instance, for the environmental dimension, the public may not be interested or keen on the efforts of companies in building a green office or minimising carbon release. Investing in the workplace dimension may just benefit the employees, as compared to the general public at large. Therefore, it is expected that the community dimension remains the primary and the easier route to opt for companies to contribute in terms of CSR. A company that contributes back to society via community dimension usually derives an instant good corporate image. Furthermore, it is the public who become a major beneficiary as companies increase involvement or contribution through the community dimension. Earning a good corporate image at the same time will grant invisible advertising and marketing towards the company. The public has a higher tendency to accept a company with a good corporate image, as compared to a not known company, especially in the financial sector. Additionally, a conscious investor will only invest into or engage financial institutions that he or she believes in or is trustworthy. Moreover, investors easily obtain visible information about companies' active involvement in CSR; hence, it reduces the asymmetrical information concern, reduces the cost of capital, and lower the companies' financial risk (Harjoto \& Jo, 2014). Additionally, Brown et al. (2006) also argued that involvement in the community dimension of CSR could help to boost companies' positive standings among regulators or authorities, in particular during a situation of possible litigation orders.

Based on the findings, another considerable point is companies' involvement in the workplace dimension of CSR. A more active employee engagement via the workplace dimension is expected to benefit companies. An active employee engagement signals concern and commitment of companies towards personnel well-being. It is expected to improve the 
productivity level, which will be translated into an improved earnings level or reduced operating cost per employee. A level of satisfaction among employees is expected to improve as more resources are channelled to strengthen the occupational safety and health aspect in companies. By doing so, it enhances the conducive and sound working environment. In fact, studies by Verwijmeren and Derwall (2010), Berk, Stanton and Zechner (2010), and Bauer, Derwall and Hann (2009) evidenced that companies with extensive employee engagement programmes enjoy better credit ratings and reduce related multiple risks, including litigation risks by unions or workers' associations or bankruptcy filings. In short, Benlemlih (2019) argued that enhancing workplace dimension engagement shall lead to better employees' treatment, solidify staff morale, and support, and enable companies to focus more resources in managing strategic initiatives, including wealth distribution matters to shareholders.

In terms of managerial and practical implications, financial institutions will continue aggressively to participate and support community-related programmes in CSR initiatives. Such initiatives send signals to stakeholders, especially the society or non-profitable organisations, that finance companies have a strong corporate citizenship behaviour by providing scholarships to needy children, extending financial aid to vulnerable groups, or sponsoring public amenities projects. The strong involvement of finance companies in community-related programmes contributes towards strengthening the branding and improving the earnings level. Therefore, it enhances the dividend payment to shareholders. Furthermore, finance companies shall continue to aggressively enhance workplace-related programmes in the CSR initiatives. Finance companies may improve the resources allocation to enhance the employees' health and safety conditions physically, emotionally, mentally, ethically, spiritually, and psychologically. Finance companies also will continue to offer better remuneration, benefits, and engagement with their employees. The strong involvement in workplace-related programmes can boost the morale and motivation of employees, which translated to higher productivity and improved earnings level. Consequently, it improves the dividend payment to shareholders. In addition, better treatment of employees improves the reputation of finance companies among regulators and oversight agencies, which can help to reduce the cost of capital when an additional cash injection is needed or required. It helps to monitor and reduce the cost of issuing debt or capital, which later translated into better earnings and a boost in the dividend payout. On the other hand, the findings inform regulators and policymakers that necessary improvements such as tax incentives or other rewards schemes will be designed to encourage greater participation of finance companies in the environmental and marketplace dimension of CSR. For instance, finance companies will be encouraged to offer innovative products to support more economic activities that contribute positively to sustainable development and environmentally friendly product development. Without additional incentives, finance companies are reluctant to support green economy sectors, which have a longer period of achieving economies of scale or breakeven points. Besides, investors may consider adopting companies with strong involvement in the community dimension and workplace dimension of corporate social responsibility, as compared to companies with participation in marketplace dimension and environmental dimensions. These findings indicated that companies that placed a greater contribution to community and workplace CSR tend to pay a higher dividend.

Moreover, in terms of theoretical implication, the findings contributed to the body of knowledge by zooming out the impact of specific CSR dimensions on dividend payout. Previously, Saeed and Zamir (2021) found that environmental and social dimensions have a negative relationship towards dividend payout in a selected emerging market, including Malaysia. Therefore, the findings of this study corroborate with Saeed and Zamir (2021) in the context of the environmental CSR dimension; however, not consistent in the context of social or community CSR dimensions. The mixed findings reflect the agency problem in both financial and non-financial companies. Managers tend to opportunistically use CSR disclosure to project favourable news or report unfavourable news through a positive tone. Besides, managers may take advantage of the CSR aspect by allocating more resources in a particular dimension while providing fewer resources in other particular dimensions in order to satisfy the shareholders or to gain shareholders' trust toward their managerial stewardship. Furthermore, the findings of this study corroborate with Trihermanto and Nainggolan (2019) in the context of the direct relationship of community or social CSR dimension with dividend payout. In fact, both studies found evidence that firms in the Indonesian and Malaysian markets prefer to participate more in the social dimension of CSR (etc., education sponsorship, charitable donation, social contribution) compared to other dimensions. In addition, the investment in the social CSR dimension improves as the firms reach a more mature stage of the corporate life cycle. However, the findings of the current study, which discovered a negative relationship between environmental CSR dimension and dividend payout, contradict Trihermanto and Nainggolan (2019), which found a direct relationship. Additionally, the findings of this study are consistent with Nguyen and Nguyen (2021), as both studies found a negative relationship between environmental and marketplace CSR dimensions with dividend payout. Nguyen and Nguyen (2021) argued that banks in an emerging market such as Vietnam prefers to spend less on CSR aspects, as they are more concerned about meeting possible future risks or shocks, like sudden dividend requests or pressure of higher dividend payment from shareholders. The consideration is prevailing if the banks are in financial constraint or difficult situation. Banks are found to spend more on CSR especially social and workplace dimensions, if they are financially unconstraint, 
have large resources to meet the future obligation and risk, including dividend payment from shareholders, or the investment in those CSR components provide greater returns and benefits, including reducing reputational, systematic, total, and idiosyncratic risks. Besides, the findings of the current study are consistent with Samet and Jarboui (2017). Both studies found a direct relationship between the social CSR dimension with dividend payout. In the same vein, allocating more resources for the social or community CSR dimension explains the commitment of financial and non-financial companies towards fulfilling and balancing the needs or expectations of various stakeholders, without compromising the obligation to meet shareholders' expectation of better returns in terms of dividend payout. Finally, the findings of the current study added to the body of literature, especially in improving the understanding of non-financial factors effects on corporate dividend policy. Consistent with the earlier work of Rakotomavo (2012), Samet and Jarboui (2017), Benlemlih (2019), and Trihermanto and Nainggolan (2019), the findings revealed the influence of non-financial factors, i.e., environmental, social, marketplace and workplace CSR dimensions towards dividend payout even among financial institutions in an emerging market. The findings also uphold the revelation by Girerd-Potin, Jimenez-Garces, and Louvet (2014) that investors and shareholders do matter to a specific CSR dimension and its eventual impact on corporate dividend policy.

\section{Conclusions}

The findings achieved the underlying objectives of the study. The results showed that there is a significantly positive correlation between community dimension and workplace dimension with dividend payout. However, there is a positive and non-significant correlation between environmental and marketplace dimensions with dividend payout. The regression analysis further indicated that there are positive relationships between community dimension and workplace dimension with dividend payout even though the relationships are non-significant. Additionally, there are negative relationships between the environmental dimension and marketplace dimension with dividend payout, and the relationships are also non-significant.

The study is limited by only focusing on the impact of CSR dimensions on dividend payout among public listed finance companies in Malaysia. Hence, the finding shall be generalised incautious for other sectors, as well as for other jurisdictions. In addition, the data concentrated on one financial year only, which might be influenced by specific events during the year of understudy. For future studies, a longitudinal approach could be adopted to assess the impact of CSR on dividend payout periodically. In addition, future studies may also extend the analysis of CSR disclosure impact on dividend payout among non-financial companies. Besides, future studies shall encompass other emerging markets' financial institutions such as ASEAN for comprehensive comparative analysis, as financial institutions play significant roles in socioeconomic well-being among developing nations.

\section{Data availability}

Underlying data

Figshare: The effect of corporate social responsibility on Malaysian financial institutions' dividend payout, https:// figshare.com/s/72c59755548ecf0b5d9e (Sallehhuddin, Keong \& Yatim, 2021a).

This project contains the following underlying data:

Data file. Consist of data for descriptive analysis, correlation analysis and multiple regression analysis

\section{Extended data}

Figshare: The effect of corporate social responsibility on Malaysian financial institutions' dividend payout, https:// figshare.com/s/688662717c1d8022d1b6 (Sallehhuddin, Keong \& Yatim, 2021b).

This project contains the following underlying data:

Data file A. List of Finance Companies

Data file B. Example of CSR Measurement Criteria (extract of items from Shirley et al. (2009), Williams and Ho (1999) and Hackston and Milne (1996).

Data are available under the terms of the Creative Commons Zero "No rights reserved" data waiver (CC0 1.0 Public domain dedication). 


\section{Author contributions}

Conceptualisation, AS, TBK and NMY; methodology, AS, TBK and NMY; formal analysis, TBK; investigation, AS and TBK; writing - original draft preparation, AS, TBK, and NMY; writing-review and editing, AS, and NMY; supervision, AS.

\section{Acknowledgements}

We would like to record acknowledge and appreciation given by Multimedia University for the direct and indirect institutional support towards the completion of the article.

\section{References}

Ahmad NNN, Haraf ASA: Environmental disclosures of Malaysian property development companies: Towards legitimacy or accountability?. Social Responsibility Journal. 2011; 9(2): 241-258. Publisher Full Text

Al-Najiar B, Kilincarslan E: What do we know about the dividend puzzle? - A literature survey. Int. J. Manag. Financ. 2019; 15(1): 205-235. Publisher Full Text

Bae K, El Ghoul S, Guedhami O, et al.: Does corporate social responsibility reduce costs of high leverage? Evidence from capital structure and product market interactions. J. Bank. Financ. 2019; 100(1): 135-150.

Publisher Full Text

Bah R, Dumontier P: R\&D intensity and corporate financial policy: Some international evidence. J. Bus. Financ. Acc. 2001; 28(5/6): 671-692. Publisher Full Text

Bauer R, Derwall J, Hann D: Employee relations and credit risk.

Social Science Research Networking Paper Series. 2009; 1-43.

Publisher Full Text

Benlemlih M: Corporate social responsibility and dividend policy. Res. Int. Bus. Financ. 2019; 47(1): 114-138.

Publisher Full Text

Berk JB, Stanton R, Zechner J: Human capital, bankruptcy and capital structure. J. Financ. 2010; 65(3): 891-926.

Publisher Full Text

Brown WO, Helland E, Smith JK: Corporate philanthropic practices. J. Corp. Finan. 2006; 12(5): 855-877.

Publisher Full Tex

Budagaga AR: Determinants of banks' dividend payment decisions: Evidence from MENA countries. Int. J. Islam. Middle East. Financ. Manag. 2020; 13(5): 847-871.

Publisher Full Tex

Bursa Malaysia: Bursa Malaysia sustainability reporting guide. Kuala Lumpur: Bursa Malaysia; 2012.

Cespa G, Cestone G: Corporate social responsibility and managerial entrenchment. J. Econ. Manag. Strateg. 2007; 16(3): 741-771. Publisher Full Text

Chauhan $Y$, Kumar SB: Do investors value the non-financial disclosure in emerging market?. Emerg. Mark. Rev. 2018; 37(3): 32-46.

Publisher Full Text

Cheung A, Hu M, Schwiebert J: Corporate social responsibility and

dividend policy. Account. Finance. 2018; 58(3): 787-816.

Publisher Full Text

Dewasiri NJ, Koralalage WBY, Azeez AA, et al.: Determinants of dividend policy: Evidence from an emerging and developing market. Manag.

Financ. 2019; 45(3): 413-429.

Publisher Full Text

El Ghoul S, Guedhami O, Kwok CCY, et al.: Does corporate social responsibility affect the cost of capital?. J. Bank. Financ. 2011; 35(9):

2388-2406.

Publisher Full Text

Fama EF, French KR: Disappearing Dividends: Changing Firm Characteristics or Lower Propensity to Pay?.J. Financ. Econ. 2001; 60(1): $3-43$. Publisher Full Text

Girerd-Potin I, Jimenez-Garces S, Louvet P: Which dimensions of socia responsibility concern financial investors?. J. Bus. Ethics. 2014; 121(4): 559-576.

Publisher Full Text

Goss A, Roberts ES: The impact of corporate social responsibility on the cost of bank loans. J. Bank. Financ. 2011; 35(7): 1794-1810.

Publisher Full Text
Hackston D, Milne M: Some Determinants of Social and Environmental Disclosures in New Zealand Companies. Account. Audit. Account. J. 1996; 9(1): 77-108

Publisher Full Text

Haji AA: Corporate social responsibility disclosures over time:

Evidence from Malaysia. Manag. Audit. J. 2013; 28(7): 647-676.

Publisher Full Text

Haniffa R, Hudaib M: Exploring the ethical identity of Islamic

banks via communication in annual reports. J. Bus. Ethics. 2007; 76(1):

97-116.

Publisher Full Text

Harjoto MA, Jo H: Legal vs. Normative CSR: Differential impact on analyst dispersion, stock return volatility, cost of capital, and firm value. J. Bus. Ethics. 2014; 128(1): 1-20.

Heal G: Corporate social responsibility: An economic and

financial framework. Geneva Pap. Risk Insur. Issues Pract. 2005; 30(1):

387-409.

Publisher Full Text

Hellsten S, Mallin C: Are "ethical" or "socially responsible" investment socially responsible?. J. Bus. Ethics. 2006; 66(4): 393-406.

Publisher Full Text

Hendijani Zadeh M: The effect of corporate social responsibility transparency on corporate payout. Int. J. Manag. Financ. 2020. (in press). Lim Y, Talha M, Junaini M, et al.: Corporate Social Responsibility Disclosure and Corporate Governance in Malaysia. International Journal of Behavioural Accounting and Finance. 2008; 1(1):

67-89.

Publisher Full Text

Kim J, Jeon Y: Dividend policy and corporate social responsibility: A comparative analysis of multinational enterprise subsidiaries and domestic firms in Korea. Emerg. Mark. Financ. Trade. 2015; 51(2): 306-319.

Publisher Full Text

KPMG: Currents of change. The KPMG survey of corporate responsibility reporting 2015. Netherlands: PwC; 2015.

Krejcie RV, Morgan DW: Determining sample size for research activities. Educ. Psychol. Meas. 1970; 30(1): 607-610.

Publisher Full Text

Margolis JD, Walsh JP: Misery loves companies: Rethinking social initiatives by business. Adm. Sci. Q. 2003; 48(2): 268-305.

Publisher Full Text

Mohanadas ND, Sallehhuddin A, Lim KP: CSR and tax aggressiveness of Malaysian listed companies: Evidence from an emerging economy. Soc. Responsib. J. 2019; 16(5): 597-612.

Publisher Full Text

Nadzri MMN: The $14^{\text {th }}$ general election, the fall of Barisan Nasional and political development in Malaysia.J. Curr. Southeast Asian Aff. 2018; 37(3): 139-171.

Publisher Full Text

Nekhili M, Nagati H, Chtioui T, et al.: Corporate social responsibility disclosure and market value: Family versus nonfamily firms. J. Bus. Res. 2017; 77(1): 41-52.

Publisher Full Text

Nguyen LT, Nguyen KV: The impact of corporate social responsibility on the risk of commercial banks with different levels of financial constraint. Asia-Pac. J. Bus. Adm. 2021; 13(1): 98-116.

Publisher Full Text

Nik Ahmad NN, Sulaiman M, Siswantoro D: Corporate social responsibility disclosure in Malaysia: An analysis of annual reports of KLSE listed companies. IIUM Journal of Economics and Management. 2003; 11(1): $51-86$ 
Parsa S, Roper I, Muller-Camen M, et al.: Have labour practices and human rights disclosures enhanced corporate accountability. The case of the GRI framework. Account. Forum. 2018; 42(1): 47-64. Publisher Full Text

Pinto G, Rastogi S, Kadam S, et al:: Bibliometric study on dividend policy. Qualitative Research Financial Market. 2020; 12(1): 72-95.

Publisher Full Text

PwC: Corporate social responsibility highlights. Bermuda: PwC; 2017.

Rakotomavo MTJ: Corporate investment in social responsibility versus dividends. Soc. Responsib. J. 2012; 8(2): 199-207.

Publisher Full Text

Robinson M, Kleffner A, Bertels S: Signaling sustainability leadership: Empirical evidence of the value of DJSI membership.J. Bus. Ethics. 2011;

101(1): 493-505

Publisher Full Text

Saeed A, Zamir F: How does CSR disclosure affect dividend payment in emerging markets?. Emerg. Mark. Rev. 2021; 46(1): 1-26.

Saleh M, Zulkifli N, Muhamad R: Corporate Social Responsibility Disclosure and Its Relation on Institutional Ownership: Evidence from Public Listed Companies in Malaysia. Manag. Audit. J. 2010; 25(6):

591-613.

Publisher Full Text

Sallehhuddin A, Keong TB, Yatim NM: The effect of corporate social responsibility on Malaysian financial institutions' dividend payout. 2021a.

Reference Source

Sallehhuddin A, Keong TB, Yatim NM: The effect of corporate social responsibility on Malaysian financial institutions' dividend payout. $2021 \mathrm{~b}$

Reference Source

Samet M, Jarboui A: Corporate social responsibility and payout decisions. Manag. Finance. 2017; 43(1): 982-998.

Selvarajah DD, Murthy U, Massilamani M: The impact of corporate social responsibility on firm's financial performance in Malaysia.
International Journal of Business \& Management. 2018; 13(3): 220-232. Publisher Full Text

Senawi A, Abdul Rahman NAY, Ahmad@Mohamed N, et al.: Corporate social responsibility practices among Malaysia top property developers. Proceedings of the Social Sciences Research (ICSSR 2016), Kuala Lumpur, Malaysia, 18-19 July. 2016.

Sheikh S: Corporate social responsibility and corporate payout policy: The impact of product market competition. Int. J. Manag. Financ. 2020; ahead-of-print. (in press).

Publisher Full Text

Shirley C, Suan AG, Leng CP, et al.: Corporate social responsibility reporting in Malaysia: An analysis of Website reporting of Second Board companies listed in Bursa Malaysia. SEG Review. 2009; 2(2): 85-98.

Sulaiman M, Abdullah N, Fatima AH: Determinants of environmental reporting quality in Malaysia. International Journal of Economics, Management and Accounting. 2014; 22(1): 63-90.

Trihermanto F, Nainggolan YA: Corporate life cycle, CSR, and dividend policy: Empirical evidence of Indonesian listed firms. Soc. Responsib. J. 2019; 16(2): 159-178.

Publisher Full Text

Verwijmeren P, Derwall J: Employee well-being, firm leverage and

bankruptcy risk. J. Bank. Financ. 2010; 34(5): 956-964.

Publisher Full Text

Williams S, Ho C: Corporate Social Disclosures by Listed Companies on Their Web Sites: An International Comparison. Int. J. Account. 1999; 34(3): 389-419.

Publisher Full Text

Yam S: The practice of corporate social responsibility by Malaysian developer. Prop. Manag. 2013; 31(1): 76-91.

Publisher Full Text

Zamir F, Saeed A: Location matters: Impact of geographical proximity to financial centers on corporate social responsibility (CSR) disclosure in emerging economies. Asia Pacific J. Manag. 2020; 37(1): 263-295. 


\section{Open Peer Review}

\section{Current Peer Review Status: ? ?}

\section{Version 1}

Reviewer Report 10 February 2022

https://doi.org/10.5256/f1000research.77265.r119878

(C) 2022 Alrazi B. This is an open access peer review report distributed under the terms of the Creative Commons Attribution License, which permits unrestricted use, distribution, and reproduction in any medium, provided the original work is properly cited.

\section{Bakhtiar Alrazi}

College of Business Management and Accounting, Universiti Tenaga Nasional, Muadzam Shah, Malaysia

Overall, the manuscript brings an interesting issue that has not been well explored in the extant literature. However, there are few areas that could be addressed by the authors to further improve the manuscript.

\section{Title}

Since the findings from the regression analysis do not show any significant effect of corporate social responsibility on the dividend payout (although correlation analysis demonstrates such a relationship), it is less appropriate to use it in the title as if the cause-

\section{Introduction} and-effect relationship is evident from the findings.

There should be a more enhanced discussion on the importance of investigating the influence of CSR on dividend payout and the decision to focus on financial institutions, other than being lacking in the literature.

- The first sentence in the fourth paragraph is more appropriate to be the last sentence of the third paragraph as it deals with the reason for examining the impact of CSR on the dividend payout.

Include a paragraph at the end of the section to describe the structure of the manuscript.

\section{Literature Review}

This section needs to be re-arranged to improve the flow of discussion. Currently, it has three broad elements - the arguments, prior literature and hypotheses.

The authors may want to begin the section with a discussion of prior literature. Since the central focus of the research is on the dimensions of CSR, it is worthy to describe each of the dimensions in this section. Currently, these dimensions are described briefly in the Methods section. For the discussion of prior empirical findings, it shall follow a certain 
theme (e.g., by country, by scope of CSR - overall, dimensions, etc.). The discussion shall bring the readers to the identification of research gaps that the authors intended to address.

Then, the section shall provide the arguments which link CSR and dividend payout. Is there any specific theory (or theories) that can be used to predict or explain the relationship? Previous literature have used one, or a combination, of the following theories: signaling theory; stakeholder theory; voluntary disclosure theory; life-cycle theory; and agency theory (e.g., Hendijani Zadeh, 2021'; Sheikh, 2022²; Saeed \& Zameer, 202133; Benlemlih, 20194; Cheung et al., 2018 ${ }^{5}$; Samet \& Jarboui, 20176; Rakotomavo, 2012 ${ }^{7}$ ). Interestingly, the authors mimicked the arguments used by Cheung et al. (2018); however, Cheung et al. (2018) ${ }^{5}$ was not cited in the arguments' paragraphs (i.e. the first two paragraphs in the Literature Review section). Also, while Cheung et al. $(2018)^{5}$ predicted a negative association between CSR and dividend payout (based on cost of capital argument), the authors predicted the opposite (based on a 'positive relationship' stated in the hypotheses). As such, the discussion on such a relationship needs to be strengthened. The discussion can begin with general premise of the theory before going into more specific elaboration into the relationship being investigated. By doing this, it can improve the development of hypotheses which currently looks like a mere listing of hypotheses.

It is not clear as to why the hypotheses only focused on CSR dimensions but neglected the overall CSR.

\section{Methods}

The research is cross sectional in nature in which the authors chose year 2017 as the year of analysis. First, the choice of 2017 is not well supported. The CSR Framework was introduced in year 2006 (made effective in year 2007) and has been superseded by a new requirement for sustainability statement. Second, based on the Literature Review section, most of the existing research conducted in the area used several years of data. Although it is stated in the limitations of the research, the fact that the authors did not find any significant association from the regression analysis, it could be due to problem with the data. Consistent with prior literature, it is more appropriate if the data were collected for several years (e.g., 2007 - 2017).

The research only analysed annual reports for CSR. Over the years, there is an increasing evidence of companies using a stand-alone report (e.g., sustainability report) and company website to communicate their CSR information to stakeholders.

The guidelines used to measure CSR information were about eight years old (i.e. between 1996 and 2009). How did the authors ensure the items included are still valid/relevant? Did the authors make attempt to benchmark the items with guidelines published by other authoritative organisations such as GRI and Bursa Malaysia?

There are 120 measurement criteria used for CSR. However, the authors only provided a sample of 20 items in the Data file. To ensure full reproducibility of the research, it is suggested for the authors to include all 120 CSR disclosure items.

One of the main issues inherent in content analysis is subjectivity of the scores assigned to measure the disclosure level. How did the authors mitigate this issue? 


\section{Results}

The analysis is based on a small number of observations $(n=32)$. It is more often for this type of research utilising data of several years. The regression model only includes the main variables (CSR) without any control variable. As a result, none of the main variables are statistically significant and the model is more likely not significant. All these issues, taken together, question the rigour of the research.

- The third paragraph in page 8 needs to be rephrased. Initially, the authors stated that "Workplace dimension had the highest impact on dividend payout". Then, it is claimed that "...no significant impact on dividend payout. The authors next concluded, based on positive coefficients, that the findings support hypotheses 2 and 4. Is it appropriate to make such a conclusion when the coefficients are not statistically significant? This is contradicting with objectivity as one of the hallmarks of scientific research.

\section{Discussion}

None of the main variables are significant. Therefore, it is not convincing as to what extent the discussion presented really relate to the actual findings of the research.

\section{Conclusions}

The conclusion needs to better reflect the regression analysis i.e. CSR did not affect the

\section{References} dividend payout of the Malaysian financial institutions.

Inconsistent referencing, e.g., in page 3, it is written as Nik Ahmad and Haraf (2011) but in the references list, it is Ahmad and Haraf (2011).

Some of the references denoted 'in press' have been published. Update the references with the latest publication year, volume, number and page number (if any).

\section{Language and typographical errors}

Below are some language and typographical errors that could be identified. Authors are recommended to check throughout the manuscript for any other error.

Pg. 3: "At the start of 2007,"

Pg. 3: "...the relationship between each dimension of CSR..."

Pg. 3: "...the effect of environmental dimension, community dimension... towards dividend payout"

Pg. 4: the numbers' formatting. Use 1,000 separator (,) more consistently, e.g., 3040 vs 2,822

Pg. 4: "...strong performing of CSR companies..." or "strong CSR performing companies"? Check also for the appropriateness of "less performing CSR companies"

Pg. 5: Check for the appropriateness of "...dividend payout in the understudy emerging markets".

Pg. 5: Consistency in writing number i.e., "...10 retail banks, one exchange, 10 investment holding companies..."

Pg. 5: "2017 data was chosen..." 
Pg. 6: "...the dividend payout for finance companies was $41.18 \underline{\%}$ "

\section{References}

1. Hendijani Zadeh M: The effect of corporate social responsibility transparency on corporate payout policies. International Journal of Managerial Finance. 2021; 17 (5): 708-732 Publisher Full Text 2. Sheikh S: Corporate social responsibility and corporate payout policy: the impact of product market competition. International Journal of Managerial Finance. 2022; 18 (1): 49-74 Publisher Full Text

3. Saeed A, Zamir F: How does CSR disclosure affect dividend payments in emerging markets?. Emerging Markets Review. 2021; 46. Publisher Full Text

4. Benlemlih M: Corporate social responsibility and dividend policy. Research in International Business and Finance. 2019; 47: 114-138 Publisher Full Text

5. Cheung $A, H u M$, Schwiebert J: Corporate social responsibility and dividend policy. Accounting \& Finance. 2018; 58 (3): 787-816 Publisher Full Text

6. Samet $\mathrm{M}$, Jarboui A: Corporate social responsibility and payout decisions. Managerial Finance. 2017; 43 (9): 982-998 Publisher Full Text

7. Rakotomavo M: Corporate investment in social responsibility versus dividends?. Social Responsibility Journal. 2012; 8 (2): 199-207 Publisher Full Text

Is the work clearly and accurately presented and does it cite the current literature? Yes

Is the study design appropriate and is the work technically sound? Partly

Are sufficient details of methods and analysis provided to allow replication by others? Partly

If applicable, is the statistical analysis and its interpretation appropriate? Partly

Are all the source data underlying the results available to ensure full reproducibility? Partly

Are the conclusions drawn adequately supported by the results? Partly

Competing Interests: No competing interests were disclosed.

Reviewer Expertise: Sustainability reporting, corporate governance, stakeholder engagement I confirm that I have read this submission and believe that I have an appropriate level of expertise to confirm that it is of an acceptable scientific standard, however I have significant reservations, as outlined above. 
Reviewer Report 20 January 2022

https://doi.org/10.5256/f1000research.77265.r119881

(C) 2022 Wasiuzzaman S. This is an open access peer review report distributed under the terms of the Creative Commons Attribution License, which permits unrestricted use, distribution, and reproduction in any medium, provided the original work is properly cited.

\section{Shaista Wasiuzzaman}

School of Business, Universiti Teknologi Brunei, Bandar Seri Begawan, Brunei

The study is an interesting one. However, there are a few improvements that can be made to the study:

1. The motivation needs to be improved and made more concise. There is a lot of discussion in the introduction regarding CSR, but the motivation to relate it to dividend policy is not strong. A discussion on why dividend policy is important, why it is an important issue in Malaysia and how it can be influenced by CSR would strengthen the motivation of the study. So, less focus on history and background and more on the motivation of the study.

Also, it would be good if you can focus the issue to finance companies instead of in general. Only in the fifth paragraph, finance companies are mentioned. Why is CSR and dividend payout important to be studied in finance companies/institutions? What is special about financial institutions in Malaysia re: CSR and dividend payout?

2. Please provide a summary of the results of the study in the introduction.

3. Please be careful... is it CSR dimensions or CSR performance/involvement (in paragraph before $\mathrm{H} 1$ and in methods section)? This is because the discussions in the literature review is all on CSR involvement/performance and not on disclosure.

4. Since the title and the objective of the study is to investigate the relationship of CSR with dividend payout, I would expect a hypothesis on the overall CSR measure with dividend payout.

5. I would expect a discussion on why you have chosen finance companies as the focus of your study.

6. I would also recommend including the overall CSR dimension instead of only its dimensions.

7. The reason for using year 2017 as being the implementation of the National Transformation Policy does not seem convincing. What does the policy have to do with CSR?

8. For results in Figure 1, it would help if you can provide some reasons why there is higher involvement in community-related programmes and lower in environmental-related ones.

9. I would suggest to include some control variables in your model. 
10. The correlations between the dimensions of CSR are quite high, especially between CR_C and CR_W. This indicates the issue of multicollinearity. This is also shown with high VIF of CR_W being greater than 4 . This is a problem when it comes to regression analysis.

11. Is the significant change value greater than 0.05 ? If it is, then it indicates a problem with your model and your regression results are invalid.

12. The problems with multicollinearity and no control variables could be the reason why your regression results are found to be insignificant. Also, since your data is across companies, you should check for heteroscedasticity.

13. Unfortunately, because all your independent variables are insignificant, the discussion provided and the managerial implications do not hold. As these variables do not affect dividend payout significantly, why would managers be worried about it?

14. Overall, I feel that the analysis and the model need to be improved.

15. There are errors in language that need to be corrected.

Is the work clearly and accurately presented and does it cite the current literature? Yes

Is the study design appropriate and is the work technically sound? Partly

Are sufficient details of methods and analysis provided to allow replication by others? Yes

If applicable, is the statistical analysis and its interpretation appropriate? Partly

Are all the source data underlying the results available to ensure full reproducibility? Yes

Are the conclusions drawn adequately supported by the results?

No

Competing Interests: No competing interests were disclosed.

Reviewer Expertise: Corporate governance, financial management, investments.

I confirm that I have read this submission and believe that I have an appropriate level of expertise to confirm that it is of an acceptable scientific standard, however I have significant reservations, as outlined above. 
The benefits of publishing with F1000Research:

- Your article is published within days, with no editorial bias

- You can publish traditional articles, null/negative results, case reports, data notes and more

- The peer review process is transparent and collaborative

- Your article is indexed in PubMed after passing peer review

- Dedicated customer support at every stage

For pre-submission enquiries, contact research@f1000.com 